\title{
Beyond Consensus: Democratic Element in ASEAN Plus Three Economic Cooperation
}

\author{
Melampaui Konsensus: Elemen Demokrasi dalam Kerja \\ Sama Keuangan ASEAN Plus Three
}

\author{
Eko NM Saputro \\ Badan Kebijakan Fiskal, Kementerian Keuangan
}

\begin{abstract}
ABSTRAK
Forum kerja sama keuangan ASEAN Plus Three (APT) telah menunjukkan kemajuan signifikan sebagai sebuah kerja sama regional. Hal ini terbukti dari beberapa perjanjian kerja sama yang disepakati dan diimplementasikan. Menariknya, kemajuan ini dicapai di tengah eksistensi berbagai sistem politik maupun ekonomi di kawasan tersebut; sebuah kondisi yang sering dijadikan alasan atas sulitnya proses demokratisisasi. Alhasil, selain menciptakan manfaat bagi ekonomi, kerja sama keuangan APT telah memfasilitasi pengenalan elemen-elemen demokrasi melalui inisiatif-inisiatif yang ada. Terkait hal ini, penelitian ini mencoba mengeksplorasi unsur-unsur demokrasi dalam inisiatif keuangan APT, khususnya pada inisiatif dukungan likuiditas regional dan fasilitas penjaminan kredit. Penelitian ini mengungkap bahwa proses pengambilan keputusan pada kedua inisiatif tersebut telah mengadopsi prinsip-prinsip dasar demokrasi prosedural. Temuan awal juga menunjukkan bahwa proses adopsi prinsip-prinsip demokrasi prosedural dipicu oleh proses bisnis kedua inisiatif tersebut, daripada perubahan ideologi politik di dalam negeri negaranegara anggota forum APT.
\end{abstract}

Kata-kata kunci: ASEAN Plus Three, kerja sama keuangan, prinsip demokrasi, tata kelola regional

The ASEAN Plus Three (APT) financial cooperation forum has shown significant progress as regional cooperation. It could be seen from several cooperation agreements that were agreed upon and implemented. Interestingly, the progress made amid the existence of various political and economic systems in the region; a condition that often used as an excuse for the difficulty of the process of democratization. As a result, besides creating economic benefits, APT's financial cooperation has facilitated the introduction of elements of democracy through existing initiatives. Furthermore, this research tries to explore the elements of democracy in APT financial initiatives, especially in regional liquidity support initiatives and credit guarantee facilities. Research reveals that the decision-making process of the two initiatives has adopted the basic principles of procedural democracy. Preliminary findings also indicate that the adoption of the principles of procedural democracy was triggered by the business process of the two initiatives rather than changes in the political ideology within the APT forum member countries.

Keywords: ASEAN Plus Three, financial cooperation, democratic principles, regional governance 
Kerja sama keuangan forum ASEAN Plus Three (APT) yang beranggotakan negaranegara ASEAN, ditambah Cina, Korea Selatan, dan Jepang, telah menunjukkan kemajuan signifikan dalam beberapa tahun terakhir. Kerja sama ini mencakup kebijakan keuangan regional, termasuk di dalamnya pengembangan pasar obligasi, akses pembiayaan, stabilisasi keuangan, dan harmonisasi pasar modal. Beberapa inisiatif kerja sama forum ini juga telah menghasilkan program nyata yang dilaksanakan di negara-negara anggotanya. Kemajuan dari kerja sama keuangan APT ini juga mengirim pesan kuat akan adanya upaya yang mengarah pada integrasi ekonomi sebagaimana terjadi di Eropa.

Sementara inisiatif kerja sama keuangan forum APT menjanjikan integrasi ekonomi yang lebih besar, beragam sistem politik dan tingkat perkembangan ekonomi dari negara-negara anggota menjadi tantangan tersendiri (Akhtar 2004, 15). Berbagai jenis infrastruktur politik serta tingkat pembangunan ekonomi yang berbeda, diyakini menjadi hambatan untuk tata kelola kerja sama di kawasan. Setiap negara anggota forum APT memiliki sistem politik yang beragam, mulai dari rezim militer di Myanmar, hingga rezim demokratis seperti halnya di Indonesia. Selain itu, dalam hal ekonomi, negara-negara anggota APT juga memiliki berbagai kondisi ekonomi yang berbeda. Mulai dari Cina atau Jepang yang memiliki ekonomi besar, hingga sejumlah ekonomi kecil di kawasan ASEAN (Beeson 2003, 259). Oleh karena itu, tidak mudah menemukan pendekatan yang tepat untuk proses pengambilan keputusan di tingkat kawasan, yang dapat memfasilitasi berbagai ideologi politik dan status ekonomi yang berbeda.

Menariknya, perkembangan kerja sama keuangan forum APT saat ini menunjukkan arah menuju tata kelola yang lebih demokratis. Dalam proses pengambilan keputusan misalnya, kerja sama in telah memberikan tanda adanya mekanisme di luar model konsensus (yang selama ini dianut khususnya oleh ASEAN), dengan diperkenalkannya mekanisme pemungutan suara dalam dua inisiatifnya, yaitu Chiang Mai Initiative Multilateralization (CMIM) dan Credit Guarantee and Investment Facility (CGIF). Bagi beberapa negara anggota forum APT, penerapan mekanisme pemungutan suara dapat menjadi tantangan serius karena berpotensi melemahkan kedaulatan politikyang mereka anut selama ini. Faktanya, tidak ada negara anggota yang mengekspresikan reaksi berlawanan terhadap mekanisme ini.

Dengan latar belakang tersebut, penelitian ini mencoba mengeksplorasi penerapan prinsip-prinsip demokrasi pada proses pengambilan keputusan dalam kerja sama keuangan APT dengan mengambil CMIM dan CGIF sebagai studi kasus. Hipotesis yang diajukan adalah bahwa elemen demokrasi prosedural telah diperkenalkan dalam kedua inisiatif tersebut, yang mencakup aspek adanya kesetaraan dalam memberikan suara, kesempatan yang sama dalam berpartisipasi dalam pengambilan keputusan, dan kemampuan untuk menentukan agenda kerja sama.

\section{Konsep Demokrasi Prosedural}

Sebagai kerangka acuan, penelitian ini mengikuti karya Robert Dahl (1989) tentang kriteria proses demokrasi, terutama untuk memberikan pemahaman dasar tentang bagaimana demokrasi prosedural beroperasi. Secara umum, karya-karya Dahl 
memberikan kontribusi terhadap pengembangan demokrasi prosedural yang mensyaratkan kriteria dasar tertentu untuk demokrasi. Dalam bukunya yang berjudul Democracy and Its Critics, Dahl (1989) menyampaikan lima kriteria demokrasi yaitu: partisipasi yang efektif, kesetaraan memilih, pemahaman yang mencerahkan, kontrol agenda, dan keterbukaan bagi siapapun. Bagi Dahl, kelima kriteria ini idealnya ada dalam sebuah demokrasi, meski sulit untuk direalisasikan secara penuh.

Dalam bukunya yang lain, On Democracy (1998, 37-38), Dahl menguraikan kelima kriteria demokrasi ini sebagai berikut. Pertama, partisipasi yang efektif diartikan sebagai sebuah proses yang memungkinkan semua orang/anggota/pihak memiliki peluang yang sama dan efektif, untuk membuat pandangan mereka diketahui oleh pihak lain. Ini artinya, demokrasi harus memfasilitasi semua pihak untuk menyampaikan pendapatnya. Kedua, kesetaran dalam memilh (memberikan suara). Kriteria ini diartikan bahwa setiap pihak harus memiliki kesempatan yang sama dan efektif dalam memberikan suara untuk memutuskan sesuatu. Frasa sama dan efektif menunjukkan perhatian Dahl bahwa demokrasi tidak hanya semata pembagian suara secara adil, namun juga bagaimana suara tersebut dapat digunakan. Ketiga, pemahaman yang mencerahkan. Dalam pandangan Dahl, demokrasi harus memberikan kesempatan yang sama dan efektif bagi setiap pihak untuk mempelajari alternatif-alternatif kebijakan yang relevan dan kemungkinan konsekuensinya. Secara implisit, Dahl ingin menegaskan perlunya pilihan-pilihan dalam sebuah demokrasi, sekaligus tahu konsekuensi dari pilihan-pilihan tersebut. Keempat, kontrol agenda. Bagi Dahl, setiap anggota memiliki kesempatan memastikan bagaimana dan apa agenda-agenda yang akan diambil jika mereka memberikan suaranya. Dengan demikian, proses demokrasi selalu bersifat terbuka manakala anggota memiliki pendapat lanjutan. Kelima, keterbukaan bagi orang dewasa. Dalam kriteria ini Dahl menegaskan perlunya semua individu dewasa untuk memiliki hak-hak warga negara, sebagaimana disebutkan pada empat kriteria pertama tadi. Hal ini untuk memastikan bahwa secara politik, semua individu yang telah dewasa memiliki kesetaraan.

Dalam penelitian ini, kelima kritieria yang Dahl ajukan sebagai elemen demokrasi prosedural dimodifikasi sebagai kerangka dasar untuk memeriksa apakah benih demokrasi telah menyebar ke dalam kerja sama keuangan di forum APT. Modifikasi utama atas konsep demokrasi prosedural Dahl dalam penelitian ini terletak pada partisipan proses demokrasi di mana Dahl lebih berfokus pada warga negara (individu/ orang), sementara penelitian ini menerapkan konsepnya pada negara-negara anggota APT.

\section{Demokrasi di Wilayah ASEAN Plus Three}

Dalam hal sistem politik, sebagian besar negara anggota forum APT kurang demokratis. Menurut Freedom House Report 2019 tentang hak politik dan kebebasan sipil, Jepang dan Korea Selatan dikategorikan sebagai negara bebas (Free), sementara Cina tetap tidak bebas. Di blok ASEAN, negara-negara ASEAN 5 (Big Five), semua diklasifikasikan dengan peringkat bebas sebagian (Partly Free). Negara-negara BCLMV (Brunei, Kamboja, Laos, Myanmar, dan Vietnam) masih dikategorikan sebagai Tidak Bebas (Not Free). Parahnya, Indonesia yang sebelumnya pernah ditekategorikan 
sebagai negara bebas, justru tidak mampu mempertahankan kemajuan demokrasinya. Konfigurasi ini mencerminkan kemajuan adopsi nilai-nilai demokrasi di kawasan tersebut, meski belum maksimal.

Tabel 1. Skor Negara-negara anggota APT berdasarkan 2019 Global Freedom

\begin{tabular}{|l|l|l|}
\hline Negara & Skor Total & Status \\
\hline Indonesia & 61 & Party Free \\
\hline Thailand & 32 & Party Free \\
\hline Malaysia & 52 & Party Free \\
\hline Singapura & 50 & Party Free \\
\hline Filipina & 59 & Party Free \\
\hline Vietnam & 20 & NotFree \\
\hline Kamboja & 25 & Not Fee \\
\hline Myanmar & 30 & Not Fee \\
\hline Brunei & 28 & Not Free \\
\hline Laos & 14 & Not Fee \\
\hline Japan & 96 & Free \\
\hline China & 10 & Not Free \\
\hline Korea Selatan & 83 & Free \\
\hline
\end{tabular}

(Sumber: Freedom House 2019)

Kurangnya kohesi politik di Asia Timur telah menghambat implementasi prinsip-prinsip demokrasi dalam kerja sama regional di Asia. Akibatnya, demokrasi tidak dapat menyebar ke seluruh kawasan APT dengan mudah. Isu-isu pelanggaran hak asasi manusia, kurangnya pemilihan yang bebas dan adil, serta keterlibatan mendalam militer dalam pemerintahan, adalah beberapa contoh yang diambil oleh para akademisi untuk menunjukkan kurangnya demokrasi di kawasan ASEAN maupun Plus Three. Pada saat Piagam ASEAN berusaha memperkuat demokrasi serta mempromosikan hak asasi manusia dan kebebasan dasar, misalnya, kasus genosida Muslim Rohingya yang terjadi di Myanmar justru merusak upaya ASEAN untuk menerapkan prinsip-prinsip demokrasi. Emmerson (2008, 82) menunjukkan bahwa Piagam ASEAN dapat bertindak sebagai pendukung sekaligus antitesis dari proses demokratisasi di kawasan Asia Tenggara, mengingat sebagian besar negara anggota ASEAN masih di bawah rejim otoriter. Sementara itu, dalam kelompok Plus Three, satu-satunya negara yang tidak demokratis adalah Cina. Kebijakan terbuka yang diterapkan beberapa tahun yang lalu tentu saja telah membuka negara yang paling padat penduduknya ini berinteraksi dengan dunia internasional, terutama dalam urusan ekonomi. Namun, meskipun Cina telah memprakarsai beberapa perubahan menuju liberalisasi, ia tetap mempertahankan sistem partai tunggal yang berlawan dengan nilai-nilai demokrasi (Shelly 2005).

Lebih lanjut, kurangnya kondisi esensial di kawasan APT telah memperlambat laju demokrasi di Asia Timur. Menurut Dahl $(1998,147)$ kondisi esensial tersebut mencakup adanya kontrol sipil atas militer dan polisi, budaya politik yang demokratis, 
dan tidak adanya intervensi oleh kekuatan asing. Dalam isu-isu spesifik, beberapa pengamat telah mengidentifikasi elemen-elemen tertentu di Asia yang berpotensi menghambat penyebaran demokrasi. Keterbatasan struktural (Christiansen, 1994), identitas nasional (Brown 2004), multi-etnis (Reilly 2006), dan dalam beberapa kasus menyangkut agama, khususnya Islam (Elisabeth 2007), dinilai sebagai penghalang bagi kawasan Asia Timur untuk mengadopsi demokrasi gaya Barat yang memerlukan kebebasan politik, homogenitas dalam nilai-nilai, penghormatan atas kebebasan dan hak asasi manusia, serta komitmen terhadap supremasi hukum.

Demokratisasi di negara-negara Asia Timur terutama berkaitan dengan cara kawasan mengadopsi demokrasi, masih merupakan sebuah perdebatan. Sen (1999) memandang demokrasi pada dasarnya adalah nilai universal yang dapat diterapkan di negara mana pun. Dengan demikian, prasyarat demokrasi dapat berbeda antara negara satu dengan yang lainnya. Pada titik ini, beberapa pemimpin negara-negara di kawasan APT berpendapat bahwa mereka telah memiliki demokrasi sendiri yaitu demokrasi gaya Asia (Reilly 2007). Soeharto dengan demokrasi Pancasila; Than Shwe dengan demokrasi yang berkembang secara disiplin (Emmerson 2008); atau Lee Kwan Yu dengan demokrasi pragmatis (Kausikan 1998). Secara sederhana, demokrasi bergerak berdasarkan nilai-nilai dan aturan bersama (Green \& Twining 2008).

Beragam versi demokrasi ala negara-negara di Asia Timur, yang pada dasarnya mencerminkan sistem politik domestik dan juga kepentingan nasional, menciptakan kesulitan tersendiri dalam membentuk lembaga regional yang demokratis. Situasi ini berbeda dibanding Eropa di mana demokrasi di tingkat kawasan merupakan perpanjangan dari nilai-nilai demokrasi di masing-masing negara anggota, yang relatif sama. Oleh karena itu, negara-negara Eropa relatif dapat membangun institusi regional berdasar demokrasi formal secara lebih mudah.

\section{Karakter Demokrasi Dalam Kerja Sama Regional Asia Timur: Perbandingan Dengan Uni Eropa}

Dalam banyak isu, regionalisme Asia Timur memiliki modalitas yang berbeda dibandingkan dengan Uni Eropa (UE). UE telah memasukkan prinsip-prinsip kebebasan, demokrasi, hak asasi manusia dan kebebasan fundamental, serta aturan hukum, ke dalam traktatnya yaitu dalam pasal 6 Perjanjian Maastricht. Sehingga, sistem demokrasi menjadi penting sebagai salah satu landasan normatif menuju regionalisme Eropa. Sementara itu, Asia memiliki doktrin nasionalis, kekuatan statistik, dan budaya, sebagai dasar (He 2004, 107). Di Eropa, institusi regional dan masing-masing pemerintah mempromosikan demokrasi (Shin 2008, 105). Sebaliknya, Acharya (2010, 354) mengklaim bahwa tidak ada kerja sama regional di Asia yang mempromosikan demokrasi ke dalam negara-negara anggotanya.

Lebih jauh, negara-negara di Asia Timur masih memegang kedaulatan negara dengan kuat atas regionalisme. Hal ini berbeda dengan UE yang telah menerapkan kerangka kerja legalistik atas anggotanya. Oleh karenanya, supremasi UE memiliki kekuatan untuk mendukung keputusan maupun kebijakannya, atas hukum nasional negara anggota (Richardson 2006, 4). Sebaliknya, negara-negara di kawasan Asia Timur masih 
perlu memastikan bahwa suatu kerja sama regional harus berdasarkan perjanjian yang dapat mengamankan kedaulatannya (Davis 2010). Akibatnya, UE relatif lebih mudah untuk membangun dan mengoperasikan institusi regionalnya berdasarkan prinsip-prinsip demokrasi, dibandingkan dengan negara-negara di kawasan Asia Timur.

Terkait proses pengambilan keputusan, integrasi Eropa memiliki pengalaman dengan konsensus dan mekanisme pemungutan suara di lembaganya. Lord $(1998,47)$ menyebutkan bahwa Dewan UE pada dasarnya cenderung menerapkan konsensus sebagai preferensi dalam mekanisme pengambilan keputusan, walaupun opsi untuk menggunakan suara terbanyak juga tersedia. Lord menambahkan bahwa super majorities sering diterapkan untuk menanggapi masalah mengenai Komunitas Ekonomi (Economic Community). Untuk mempercepat proses pengambilan keputusan, Parlemen Eropa melibatkan apa yang disebut sebagai prosedur pengambilan keputusan bersama (co-decision procedure) untuk menangani isu-isu spesifik seperti pasar internal, lingkungan, dan perlindungan konsumen (Laffan \& Mazey 2006, 44). Kemajuan ini dapat dipandang sebagai pergeseran dalam proses pengambilan keputusan UE, dari pengambilan keputusan teknokratis menuju kepada keputusan yang lebih berdampak menentukan terhadap perwakilan masyarakat yang dipilih secara langsung (Delmatino 2005, 22). Alhasil, prinsip-prinsip demokrasi berkembang dalam proses-proses yang berlangsung di UE.

Lebih lanjut, hubungan antara demokrasi dan status ekonomi di kawasan Asia Timur masih merupakan perdebatan. Beberapa fakta menunjukkan hal ini. Sebagai contoh, ditemukan bahwa orientasi pasar yang kuat adalah kata kunci untuk demokrasi yang sukses di Taiwan (Wood 2004, 61). Selain itu, transisi demokrasi Korea Selatan juga dimulai dengan pertumbuhan ekonomi yang berkelanjutan (Haynes 2001, 97). Di sisi lain, meski mampu mempertahankan tingkat ekonomi yang tinggi, Singapura masih tetap merupakan negara yang kurang demokratis dibanding Indonesia (Emmerson 2008, 79). Sedangkan China yang menikmati pertumbuhan ekonomi tertinggi di dunia dalam beberapa tahun terakhir, masih berada di bawah rezim otoriter. Dalam kasus yang berbeda, reformasi politik yang berkembang di Indonesia, justru didorong oleh gejolak ekonomi ketika kekayaan rakyatnya merosot. Menurut pandangan Laothamatas $(1997,17)$ pembangunan ekonomi tidak diperlukan atau setidaknya tidak cukup untuk menjadi syarat bagi transisi demokrasi di Asia Timur maupun Asia Tenggara.

Beberapa pihak percaya bahwa ketergantungan ekonomi dapat menyebabkan penyebarluasan benih-benih demokrasi. Kondisi ini dapat dijelaskan dari adanya ketergantungan ekonomi satu sama lain, yang berkontribusi untuk menstabilkan transisi demokrasi (Lind dalam Acharya 2010). Selain itu, ketergantungan ekonomi juga dikaitkan dengan perdamaian di tingkat internasional (Acharya 2010, 352). Dalam hal ini, suatu kerja sama regional, sampai batas tertentu, akan mendorong anggotanya untuk lebih transparan terhadap situasi domestik mereka. Namun, Shin \& Co (2010, 32) menemukan bahwa masyarakat Asia Timur pada dasarnya cenderung lebih mengutamakan keamanan ekonomi atau kesetaraan ekonomi, daripada kebebasan untuk membangun demokrasi. Oleh karena itu, meski peran ekonomi terhadap demokrasi di kawasan ini tetap kabur, tidak cukup alasan untuk mengeluarkannya dari diskusi akademis. 


\section{Kemajuan Kerja Sama Keuangan ASEAN Plus Three}

Tumbuhnya saling ketergantungan dalam hubungan ekonomi, khususnya perdagangan, telah mendorong negara-negara Asia Timur berinteraksi secara lebih dekat. Dengan mengambil krisis keuangan Asia 1997 sebagai momentum, para pemimpin dari 13 negara APT berinisiatif untuk bekerja sama dalam urusan luar negeri, kerja sama ekonomi, dan masalah keuangan-moneter (Hidetaka 2005). Pada tahun 1999, beberapa menteri anggota forum APT memulai proses-proses sektoral di bawah kerangka APT (Suzuki 2004, 7). Dalam perkembangan selanjutnya, meskipun berbagai isu juga dibahas dalam proses-proses di bawah forum APT, kerja sama keuangan-moneter tampaknya secara eksklusif mendapatkan fokus lebih, dibanding masalah-masalah lain karena trauma krisis Asia tak terlupakan bagi beberapa anggota APT (Pempel 2010, 219). Negara-negara APT mengakui bahwa mereka perlu menemukan cara mereka sendiri untuk menghadapi krisis ekonomi, karena AS tidak dapat lagi diandalkan untuk krisis ekonomi semacam itu (Soesastro 2003). Tumbuhnya saling ketergantungan ekonomi di Asia Timur juga diyakini sebagai batu loncatan menuju regionalisme keuangan di Asia Timur.

Namun, regionalisme keuangan di Asia Timur menghadapi banyak tantangan. Pada kenyataannya, kawasan ini berlimpah dengan berbagai nilai, sistem politik, dan tingkat perkembangan ekonomi yang beragam, yang dapat menghambat kerja sama dan integrasi negara-negara di Asia Timur. Perselisihan teritorial dan klaim kedaulatan yang tumpang tindih, tetap belum terselesaikan di bawah permukaan politik yang relatif damai (Alatas 2001). Bagi He $(2004,118)$ prinsip kedaulatan juga menghambat regionalisme Asia. Selain itu, kerja sama akan menjadi kompleks dan menantang dengan keragaman Asia Timur serta perbedaan dalam tingkat keterlibatan terhadap sistem internasional (Beeson 2003, 264).

Dalam sudut pandang optimis, Davis (2010, 45) berpendapat bahwa regionalisme masih mungkin dibangun walaupun suatu kawasan menghadapi berbagai perbedaan dalam sistem sosial ekonomi, politik, dan budaya. Stubbs (2002, 463) memandang bahwa proses-proses di bawah forum APT memfasilitasi upaya membangun rasa kesamaan tujuan dan identitas Asia Timur yang mengarah pada kemudahan bentuk regionalisme. Paralel dengan Stubbs, Emmerson $(2008,12)$ menunjukkan bahwa regionalisme secara sengaja membawa negara, masyarakat, atau ekonomi di tingkat yang berbeda ke arah tujuan dan kegiatan bersama. Perubahan dinamika politik saat ini antara dua kekuatan utama dia Asia, Jepang dan Cina, diyakini justru berkontribusi dalam mempromosikan kerja sama yang lebih erat di kawasan ini, mengingat beberapa pihak berupaya mencari cara untuk memastikan kestabilan kawasan (Chey 2009, 466).

\section{Perkembangan Chiang Mai Initiative Multilateralization}

Seperti disebutkan sebelumnya, inisiatif paling maju dari kerja sama keuangan APT adalah CMIM dan CGIF. CMIM merupakan dukungan likuiditas multilateral yang bertujuan mengatasi kesulitan neraca pembayaran dan likuiditas jangka pendek, sekaligus melengkapi pengaturan internasional yang telah ada (APT 2010). CMIM dibangun sebagai mekanisme mandiri (self-help mechanism) di kawasan, melanjutkan inisiatif 
Chiang Mai Initiative (CMI), yang sebelumnya telah diprakarsai oleh para Menteri Keuangan APT pada tahun 2000 untuk membantu negara-negara di Asia yang terkena krisis, dengan pendekatan bilateral. Bedanya, CMIM beroperasi berdasarkan pada kontrak tunggal dan bukan perjanjian bilateral seperti yang digunakan dalam CMI. Pengalaman menantang selama Krisis Keuangan Asia 1997 dan keterlibatan kontroversial dari Dana Moneter Internasional (IMF) tentang manajemen krisis, telah mendorong kawasan untuk memperkuat mekanisme asuransi mandiri dalam menghadapi krisis ekonomi (Jomo 2010, 47). Hal ini juga menjadi respon atas keengganan AS untuk memberikan bantuan keuangan ketika beberapa anggota APT mengalami krisis ekonomi (Yeo 2010, 326).

CMIM diyakini akan membangun lembaga kolektif di masa depan untuk mewujudkan gagasan Dana Moneter Asia (Asian Monetary Fund/AMF) yang gagal karena tidak adanya dukungan dari AS (Saputro 2017). Secara teknis, CMIM memberikan dukungan likuiditas melalui mekanisme swap mata uang. Dalam hal ini, negara yang membutuhkan likuiditas akan menerima dukungan dana dari negara anggota APT dalam bentuk dolar Amerika Serikat untuk meningkatkan cadangan devisa. Nantinya, negara penerima bantuan akan mengembalikan sejumlah dana yang diterima dalam mata uangnya.

Perjanjian CMIM resmi mulai berlaku pada 24 Maret 2010 dengan modal awal USD 120 miliar (APT 2010). Total dana ini terdiri dari 20 persen dana yang berasal dari negara-negara anggota ASEAN, dan 80 persen sisanya disediakan oleh negara-negara Plus Three (Jepang, Korea Selatan, dan China). Terdapat 27 pihak dalam CMIM, yang terdiri dari 13 Otoritas Keuangan dan 13 Bank Sentral dari negara-negara anggota APT, ditambah satu Otoritas Moneter Hong Kong (HKMA). Total dana CMIM telah meningkat hingga USD 240 miliar untuk meningkatkan kapasitasnya dalam memberikan dukungan keuangan.

Dalam rangka mewujudkan fungsinya sebagai suplemen dari lembaga internasional yang ada, CMIM menciptakan pengaturan hubungan dengan IMF, yang disebut sebagai IMF-linked portion. Porsi ini mewajibkan negara-negara anggota APT untuk membuat kerja sama dengan IMF, ketika mereka akan mengaksesnya. Porsi ini awalnya senilai 80 persen dari total dana CMIM. Sisanya yang 20 persen merupakan dukungan dana yang dapat ditarik oleh negara anggota APT, tanpa harus terikat kerja sama dengan IMF. Porsi ini lebih dikenal sebagai IMF de-linked portion. Dalam perkembangan selanjutnya, sebagian besar negara anggota ASEAN mengusulkan untuk meningkatkan IMF de-linked portion agar memiliki akses lebih banyak terhadap fasilitas CMIM, tanpa keterlibatan IMF. Pada 2012, porsi IMF-linked portion berkurang menjadi 70 persen, yang memungkinkan negara-negara anggota APT mengakses dana dukungan CMIM lebih besar (30 persen), tanpa terlibat program-program IMF.

\section{Perkembangan Credit Guarantee and Investment Facility}

Inisiatif lainnya di bawah kerja sama keuangan APT adalah Fasilitas Jaminan Kredit dan Investasi (Credit Guarantee and Investment Facility/ CGIF). Sebelumnya, inisiatif ini disebut sebagai Mekanisme Jaminan Kredit dan Investasi (Credit Guarantee 
and Investment Mechanism/CGIM), sebelum akhirnya pada pertemuan mereka bulan Mei 2010, para menteri keuangan APT sepakat untuk mengubah nama tersebut.

CGIF bertujuan untuk mempromosikan pembangunan ekonomi, ketahanan pasar keuangan, dan mencegah gangguan atas tatanan keuangan internasional, dengan mengembangkan penggunaan mata uang lokal yang likuid serta pasar obligasi regional. Pada langkah awal, CGIF berfokus pada jaminan kredit daripada fasilitas investasi. Fasilitas ini beroperasi melalui peningkatan kredit untuk obligasi korporasi di kawasan APT, dalam mata uang lokal. Dengan mendapatkan peningkatan kredit, obligasi korporasi diharapkan memiliki lebih banyak kemungkinan untuk memperoleh akses pasar.

Total dana awal CGIF adalah USD 700 juta (APT 2010). Dana tersebut dikelola oleh Asian Development Bank (ADB) sebagai wali amanat, sementara negara-negara anggota forum APT menjadi kontributornya. Secara praktis, ADB akan mengelola semua aset CGIF. Keterlibatan ADB dalam CGIF mencerminkan peran penting ADB sebagai pemain non-negara (non-state actor) di kawasan (Jayasuriya 2009). Di tingkat operasional, begitu sebuah perusahaan memenuhi standar minimum, ADB akan menilai kelayakan obligasi korporasi tersebut untuk mendapatkan peningkatan kredit dengan menerapkan apa yang disebut sebagai standar teknis internasional.

\section{Pengambilan Keputusan dalam Chiang Mai Initiative Multilateralization}

Terdapat dua tingkat badan pembuat keputusan dalam CMIM, yaitu Badan Pembuat Keputusan Tingkat Menteri (Ministerial Level Decision-Making Body/MLDMB) dan Badan Pembuat Keputusan Tingkat Eksekutif (Executive Level Decision-Making Body/ELDMB) (APT 2010). Berdasarkan Articles of Agreeement CMIM, kedua badan ini dibentuk berdasarkan isu-isu yang mereka tangani. MLDMB berwenang untuk memberikan keputusan mengenai masalah-masalah mendasar seperti ukuran kontribusi CMIM dari masing-masing anggota, jumlah maksimum swap untuk penarikan dan pembaruan, ketentuan partisipasi, ketentuan pemulihan untuk setiap anggota yang mengusulkan untuk berpartisipasi kembali, atau hal-hal lain yang disepakati sebagai masalah mendasar (fundamental issues). Anggota MLDMB adalah 13 Menteri Keuangan negara-negara anggota APT.

Dalam praktiknya, setiap keputusan MLDMB hanya efektif melalui mekanisme konsensus. Hal ini berarti bahwa setiap keputusan MLMB membutuhkan persetujuan bulat dari para anggota. Tidak ada mekanisme pemungutan suara di MLDMB. Untuk menghindari stagnasi dalam proses pengambilan keputusan MLDMB, masalah mendasar yang akan diputuskan, harus dikonsultasikan terlebih dahulu dengan ELDMB yang pada dasarnya bekerja di tingkat teknis. Dalam hal ini, pertemuan MLDMB harus dalam format tatap muka, tanpa ada kesempatan untuk menggunakan teknologi audio visual apapun. Untuk masalah tingkat eksekutif/operasional, proses pengambilan keputusan menjadi ranah ELDMB. Masalah eksekutif lebih terkait pada isu-isu operasional seperti persetujuan penarikan dana, persetujuan atas pembaruan penarikan dana, pengabaian atas kondisi-kondisi tertentu, pengumunan atas gagal bayar, dan persetujuan untuk tidak ikut serta berpartisipasi dalam membantu negara lain. 
ELDMB terdiri dari 13 perwakilan Kementerian Keuangan dari negara-negara anggota APT, ditambah 14 perwakilan Bank Sentral dari negara-negara anggota APT termasuk Hong Kong.

Dalam hal proses pengambilan keputusan, selain memiliki mekanisme konsensus, ELDMB juga dilengkapi dengan mekanisme pemungutan suara. Suara dari masing-masing anggota ELDMB dibagi berdasarkan kontribusi negara-negara anggota dalam CMIM. Setiap keputusan mengenai masalah-masalah tingkat eksekutif dinyatakan efektif jika setidaknya dua pertiga (2/3) dari pemegang hak suara efektif setuju (APT 2010). Hak suara yang efektif adalah hak suara dari setiap anggota CMIM dikurangi jumlah suara dari setiap anggota CMIM yang menyatakan tidak ikut berpartisipasi, ditambah pihak yang mengajukan dana bantuan. Tabel 2 berikut menunjukkan distribusi kekuatan suara anggota-anggota CMIM.

Tabel 2

Kontribusi dan pembagian suara dalam CMIM ${ }^{1}$

\begin{tabular}{|c|c|c|c|c|c|c|c|c|c|c|c|}
\hline \multirow{3}{*}{$\begin{array}{l}\text { Coun- } \\
\text { tries }\end{array}$} & & \multirow{3}{*}{\multicolumn{2}{|c|}{$\begin{array}{c}\text { Financial Coun- } \\
\text { tribution } \\
\text { (miliar USD) }\end{array}$}} & \multirow{3}{*}{\multicolumn{2}{|c|}{ Share (\%) }} & \multirow{3}{*}{$\begin{array}{l}\text { Pur- } \\
\text { chasing } \\
\text { Multi- } \\
\text { ple }\end{array}$} & \multirow{3}{*}{$\begin{array}{c}\text { Max.Swap } \\
\text { Amount } \\
\text { (miliar USD) }\end{array}$} & \multirow{3}{*}{$\begin{array}{l}\text { Basic } \\
\text { Vote }\end{array}$} & \multirow{3}{*}{$\begin{array}{c}\text { Vote } \\
\text { based on } \\
\text { Contribu- } \\
\text { tion }\end{array}$} & \multirow{2}{*}{\multicolumn{2}{|c|}{ Total Voting Power }} \\
\hline & & & & & & & & & & & \\
\hline & & & & & & & & & & & \\
\hline \multicolumn{2}{|c|}{ Plus Tiga } & \multicolumn{2}{|c|}{192.00} & \multicolumn{2}{|l|}{80,00} & & 117.30 & 9.60 & 192.00 & 201.60 & 71.59 \\
\hline \multirow{2}{*}{ China } & $\begin{array}{l}\text { China } \\
\text { ( K e - } \\
\text { cuali } \\
\text { Hong } \\
\text { Kong) }\end{array}$ & \multirow{2}{*}{76.80} & 68.40 & \multirow{2}{*}{32.0} & 28,50 & 0,5 & 34.20 & 3.20 & 68.40 & 71.60 & 25.43 \\
\hline & $\begin{array}{l}\text { Hong- } \\
\text { k o n g }\end{array}$ & & 8.40 & & 3,50 & 2.5 & 6.30 & 0,00 & 8.40 & 8.40 & 2.98 \\
\hline \multicolumn{2}{|l|}{ Jepang } & \multicolumn{2}{|l|}{76.80} & \multicolumn{2}{|l|}{32.00} & 0,5 & 38.40 & 3.20 & 76.80 & 80,00 & 28.41 \\
\hline \multicolumn{2}{|l|}{ Korea } & \multicolumn{2}{|l|}{38.40} & \multicolumn{2}{|l|}{16.00} & 1 & 38.40 & 3.20 & 38.40 & 41.60 & 14.77 \\
\hline \multicolumn{2}{|l|}{ ASEAN } & \multicolumn{2}{|l|}{48.00} & \multicolumn{2}{|l|}{20.00} & & 126.20 & 32.00 & 48.00 & 80,00 & 28.41 \\
\hline \multicolumn{2}{|c|}{ Indonesia } & \multicolumn{2}{|l|}{9.104} & \multicolumn{2}{|l|}{3.793} & 2.5 & 22.76 & 3.20 & 9.104 & 12.304 & 4.369 \\
\hline \multicolumn{2}{|c|}{ Thailand } & \multicolumn{2}{|l|}{9.104} & \multicolumn{2}{|l|}{3.793} & 2.5 & 22.76 & 3.20 & 9.104 & 12.304 & 4.369 \\
\hline \multicolumn{2}{|c|}{ Malaysia } & \multicolumn{2}{|l|}{9.104} & \multicolumn{2}{|l|}{3.793} & 2.5 & 22.76 & 3.20 & 9.104 & 12.304 & 4.369 \\
\hline \multicolumn{2}{|c|}{ Singapura } & \multicolumn{2}{|l|}{9.104} & \multicolumn{2}{|l|}{3.793} & 2.5 & 22.76 & 3.20 & 9.104 & 12.304 & 4.369 \\
\hline Filipina & & 9.104 & & 3.793 & & 2.5 & 22.76 & 3.20 & 9.104 & 12.304 & 4.369 \\
\hline
\end{tabular}

1 Dalam mekanisme pemungutan suara, masing-masing pihak dari negara yang sama (kecuali Otoritas Moneter Hong Kong/HKMA) harus bersatu karena kekuatan memilih mewakili negara, bukan para pihak (Kementerian Keuangan atau Bank Sentral). Jika para pihak dalam satu negara memiliki posisi yang berbeda, suara mereka akan dihitung sebagai abstain. 


\begin{tabular}{|l|l|l|l|l|l|l|l|l|}
\hline Vietnam & 2,00 & 0,833 & 5 & 10.00 & 3.20 & 2,00 & 5.20 & 1.847 \\
\hline Kamboja & 0,24 & 0,100 & 5 & 1.20 & 3.20 & 0,24 & 3.44 & 1.222 \\
\hline Myanmar & 0,12 & 0,050 & 5 & 0,60 & 3.20 & 0,12 & 3.32 & 1.179 \\
\hline Brunei & 0,06 & 0,025 & 5 & 0,30 & 3.20 & 0,06 & 3.26 & 1.158 \\
\hline Lao PDR & 0,06 & 0,025 & 5 & 0,30 & 3.20 & 0,06 & 3.26 & 1.158 \\
\hline Total & 240.00 & 100.00 & & 243,50 & 41.60 & 240.00 & 281.60 & 100.00 \\
\hline
\end{tabular}

(Sumber: ASEAN Plus Three 2012)

Dalam hal format pertemuan, pertemuan ELDMB diselenggarakan dalam format tatap muka. Namun, terdapat kemungkinan untuk melakukan pertemuan melalui teleconference atau pertemuan dalam bentuk komunikasi tertulis, jika satu atau lebih negara anggota tidak mungkin menghadiri pertemuan tatap muka. Selain itu, sebelum mekanisme pemungutan suara diadakan, penyediaan semua data dan informasi yang terkait dengan negara yang meminta dukungan dana, khususnya kondisi ekonomi terakhir, harus didistribusikan kepada semua pihak sebagai pertimbangan. Semua pihak juga harus memiliki informasi yang cukup tentang agenda, waktu, format, dan hal-hal lain dari pertemuan tersebut. Bisa ditekankan bahwa pandangan, atau bahkan keberatan tentang pengaturan proses pengambilan keputusan dimungkinkan untuk disampaikan oleh anggota jika dirasa perlu.

Dua mekanisme berbeda yang diterapkan pada badan pengambilan keputusan CMIM, pada dasarnya dibentuk sebagai respon atas tingkat urgensi masalah yang dihadapi. Ketika masalah tersebut terkait hal-hal operasional yang membutuhkan tanggapan cepat dan tidak mengganggu keanggotaan suatu negara dalam CMIM, mekanisme pemungutan suara diterapkan. Mekanisme ini merupakan alat pragmatis bagi para pihak dalam CMIM, untuk mempercepat proses pengambilan keputusan. Namun demikian, apabila masalah yang dihadapi menyangkut isu sensitif seperti kontribusi, maka CMIM memberikan hak veto kepada semua anggota, melalui mekanisme konsensus, yang memaksa adanya persetujuan dengan suara bulat.

\section{Pengambilan Keputusan dalam Credit Guarantee and Investment Facility}

Berdasarkan Perjanjian CGIF, terdapat dua organ pengambilan keputusan CGIF, yaitu Pertemuan para Kontributor (Meeting of Contributors) dan Rapat Dewan Direksi (Board of Directors Meeting). Pertemuan para kontributor merupakan lembaga/forum pengambil keputusan tertinggi di CGIF. Kontributor CGIF terdiri dari negara-negara anggota APT, termasuk Japan Bank for International Cooperation (JBIC) mewakili Pemerintah Jepang, ditambah ADB. Selain itu, pertemuan para kontributor memiliki kekuatan yang luas termasuk menentukan tujuan strategis, meninjau kinerja, memilih ketua dan anggota direksi CGIF. Bahkan, forum ini juga memiliki kewenangan untuk menunda atau menghentikan operasional CGIF. Dalam kaitan ini, kontribusi modal awal yang disetorkan oleh tiap anggota mencerminkan hak kepemilikan (saham) yang 
akan digunakan dalam proses pengambilan keputusan CGIF. Dari total USD 70o juta, Jepang dan Cina masing-masing menyumbang USD 200 juta; Korea Selatan USD 100 juta; ADB sebanyak USD 130 juta; dan ASEAN secara bersama menyetor USD 70 juta (ADB 2010).

Setiap tahun, pertemuan para kontributor diadakan pada lima bulan setelah akhir Tahun Anggaran. Jika diperlukan, rapat kontributor khusus dapat dilaksankan jika terdapat kontributor yang memegang setidaknya 10\% dari saham, meminta untuk dilakukan. Dalam hal ini, kehadiran fisik kontributor tidak diperlukan karena partisipasi melalui telepon, perangkat komunikasi lain, atau bahkan sarana elektronik lainnya dianggap sebagai sebuah kehadiran. Pengaturan ini memungkinkan semua kontributor untuk terlibat dalam proses pengambilan keputusan. Kuorum rapat ditentukan berdasarkan mayoritas jumlah kontributor yang ada, yang secara kolektif memiliki mayoritas sederhana dari total saham yang dimiliki. Aturan mayoritas sederhana juga diterapkan dalam mekanisme pemungutan suara. Semua hal yang disampaikan dalam pertemuan para kontributor akan diputuskan oleh para kontributor yang hadir, dan secara kolektif memegang mayoritas saham yang diwakili dalam pertemuan tersebut. Dalam hal kontributor tidak dapat menghadiri pertemuan tersebut, mereka dapat memberikan suara melalui perwakilannya, dengan terlebih dahulu menyampaikannya kepada direksi.

Badan pembuat keputusan kedua di CGIF adalah Dewan Direksi, yang terdiri dari delapan anggota termasuk Kepala Eksekutif (Chief Executing Officer/CEO). Badan ini terutama mewakili dan melindungi kepentingan Kontributor. Berdasarkan kontribusi mereka dalam CGIF, China dan JBIC masing-masing berhak untuk menempatkan dua direktur, sementara ASEAN (sebagai satu kelompok), Korea Selatan, dan ADB masing-masing seorang direktur. CEO, juga menjadi anggota Direksi dan memiliki hak suara yang sama dengan anggota lainnya. Direksi memastikan bahwa manajemen CGIF beroperasi dengan baik dan sepenuhnya sesuai dengan Perjanjian CGIF. Hal ini dilakukan untuk memastikan bahwa keputusan strategis rapat para kontributor dilaksanakan dengan sepenuhnya. Secara umum, Dewan Direksi meninjau rencana bisnis, anggaran, serta hal-hal operasional dan keuangan lainnya.

Direksi harus bertemu setidaknya empat kali dalam setahun. Rapat tambahan dimungkinkan untuk diadakan atas permintaan setidaknya dua anggota direksi. Mirip dengan pengaturan pertemuan para kontributor, direksi juga dapat menggunakan sarana komunikasi dan elektronik sebagai media alternatif jika terdapat direktur yang tidak dapat menghadiri rapat secara fisik. Penggunaan wakil juga diizinkan jika direktur tidak dapat berpartisipasi dalam rapat apa pun.

Perhitungan mayoritas sederhana diterapkan untuk kuorum serta mekanisme pemungutan suara untuk segala hal yang diajukan ke rapat direksi. Setiap direktur memiliki hak satu suara. Pada tahap ini, ketua Dewan Komisaris berhak untuk memiliki satu suara tambahan jika terdapat jumlah suara yang sama. Selain itu, anggota direksi diharuskan untuk tidak mengikuti pemungutan suara yang berpotensi menimbulkan benturan kepentingan. Semua peserta dalam pertemuan para kontributor maupun rapat dewan direksi berhak atas informasi yang sama terkait materi, agenda, waktu, dan tempat sebelum pertemuan. Pemberian informasi pada dasarnya penting untuk menjamin bahwa semua peserta dapat terlibat dalam proses pengambilan keputusan 
secara adil.

Berbeda dari CMIM yang masih mempertahankan mekanisme konsensus dalam proses pengambilan keputusannya, CGIF hanya menerapkan mekanisme pemilihan suara. Karakter kegiatan CGIF yang lebih bersifat komersial mendorong adanya pengutamaan operasional bisnis yang efektif, dibanding isu kedaulatan para kontributor, layaknya yang terjadi pada CMIM. Lebih lanjut, partisipasi JBIC dan ADB dalam CGIF menunjukkan dua hal. Pertama, terkait dengan kriteria Dahl mengenai keterbukaan (inclusion). Keterlibatan kedua lembaga tersebut menunjukkan adanya keterbukaan untuk menerima lembaga di luar negara (non-state actor) dalam proses kerja sama di kawasan APT. Dengan kata lain, forum kerja sama keuangan APT telah memberikan ruang bagi aktor lain untuk turut serta berpartisipasi dalam menentukan arah kerja sama.

Kedua, masalah kedaulatan tidak lagi sensitif, karena CGIF beroperasi secara komersial. Perlu dicatat bahwa CGIF didirikan untuk membantu obligasi korporasi, bukan obligasi pemerintah (sovereign bond). Oleh karena itu, sifat bisnis operasinya harus komersial (berorientasi laba) dan bebas dari konflik kepentingan. Penerapan mekanisme konsensus dalam kegiatan komersial akan berpotensi membuahkan hasil yang tidak pasti, mengingat penolakan satu pihak akan berpotensi melahirkan keputusan yang tidak tegas, dan menghilangkan potensi keuntungan. Selain itu, adanya pengaturan bagi anggota dewan direksi CGIF yang diminta untuk tidak terlibat dalam pengambilan keputusan yang berpotensi mengakibatkan konflik kepentingan, menunjukkan bahwa CGIF beroperasi secara komersial. Normalnya, jika sebuah lembaga bergerak secara non-komersial, keberadaan perwakilan negara dalam negara justru harus menyampaikan/membela kepentingan nasionalnya.

\section{Prinsip-prinsip Demokrasi dalam Proses Pengambilan Keputusan}

Dari diskusi mengenai proses pengambilan keputusan dalam CMIM dan CGIF, dapat dikatakan bahwa inisiatif kerja sama keuangan forum APT telah mengadopsi beberapa prinsip demokrasi. Temuan ini sesuai dengan konsep Dahl (1998) tentang kriteria proses demokratisasi. Pertama, selain mempertahankan mekanisme konsensus sebagai nilai dasar dari proses pengambilan keputusan di ASEAN, mekanisme pemungutan suara telah diperkenalkan ke dalam kerja sama keuangan regional forum APT. Dalam kaitan ini, mekanisme konsensus telah memfasilitasi semua anggota berpartisipasi secara efektif melalui diskusi dan konsultasi. Prinsip ini menjamin semua anggota untuk memberikan pandangan mereka secara adil tentang masalah-masalah yang relevan.

Lebih lanjut, inisiatif CMIM dan CGIF juga telah mendistribusikan hak suara berdasarkan nilai kontribusi masing-masing pihak, untuk memastikan baik kepentingan kontributor besar maupun kecil terfasilitasi secara adil. Selain itu, kedua inisiatif ini juga telah mengupayakan partisipasi maksimum bagi semua pihak dalam proses pengambilan keputusan, melalui penggunaan alat komunikasi sebagai wahana alternatif maupun melalui perwakilan. Pilihan untuk menggunakan perangkat elektronik maupun sarana komunikasi lainnya sebagai pengganti pertemuan tatap muka, mer- 
upakan cara untuk memfasilitasi para pihak dalam kerja sama keuangan APT demi dapat menggunakan hak-hak mereka secara efektif. Dahl (1998) menekankan bahwa setiap pihak harus memiliki kesempatan yang sama dan efektif untuk memilih, sehingga suara mereka dapat dinilai setara. Namun demikian, diperlukan penelitian lebih lanjut untuk menyelidiki apakah semua anggota CMIM maupun CGIF dapat mendiskusikan atau memberikan suara mereka secara bebas, tanpa adanya tekanan dari negara manapun. Studi lebih lanjut ini juga dapat digunakan untuk mengetahui apakah keputusan dalam CMIM atau CGIF tidak akan memengaruhi kerja sama lainnya, baik secara regional maupun bilateral.

Adanya pemberian informasi yang sama kepada semua peserta, sebagai persyaratan wajib sebelum proses pengambilan keputusan CMIM atau CGIF, juga menunjukkan bahwa prinsip demokrasi telah diadopsi dalam kerja sama keuangan forum APT. Ketentuan ini memastikan bahwa setiap anggota CMIM maupun CGIF memiliki kesempatan yang sama untuk mempelajari masalah yang akan diputuskan. Hal ini pada dasarnya mengikuti kriteria Dahl tentang pemahaman yang mencerahkan (enlightened understanding). Dengan bahan dan sumber informasi yang sama, setiap anggota memiliki pertimbangan yang cukup untuk membangun posisinya, dan memperkirakan konsekuensi yang akan terjadi sebagai akibat dari pengambilan sebuah posisi tertentu.

Kriteria demokrasi prosedural lain yang muncul dalam kerja sama keuangan APT adalah adanya kemampuan yang sama di antara para pihak untuk mengendalikan agenda bersama. Dalam kaitan ini, komposisi kontribusi CGIF misalnya, telah memenuhi kriteria dimaksud karena semua kontributor CGIF memiliki setidaknya USD 70 juta (10\% dari USD 70o juta), yang memungkinkan mereka untuk dapat mengajukan agenda guna dibahas bersama. Dengan kata lain, kemampuan untuk mengendalikan agenda tidak hanya dimiliki oleh kontributor besar semata.

\section{Simpulan}

Perkembangan ekonomi regional di Asia Timur, telah menunjukkan adanya adopsi prinsip-prinsip demokrasi prosedural ke dalam proses pengambilan keputusan kerja sama keuangan khususnya kawasan APT. Dalam hal ini, kerja sama tersebut secara formal mencakup konsensus dan mekanisme pemungutan suara sebagai dasar dari proses pengambilan keputusan. Kedua mekanisme ini memberikan tingkat keterikatan yang lebih besar dalam menghadapi krisis keuangan regional dan kerangka liberalisasi pasar obligasi. Adanya kekuatan hak suara yang sama, kesempatan untuk memberikan suara melalui berbagai media, kesetaraan dalam mengakses informasi yang relevan, dan kemampuan untuk mengendalikan agenda kerja sama, telah membangun jalan bagi kawasan APT menjadi lebih demokratis. Kerja sama keuangan APT, disadari atau tidak, telah mendorong negara-negara anggotanya yang belum demokratis untuk mendukung prinsip-prinsip demokrasi dalam derajat tertentu.

Lebih jauh, keterlibatan ADB sebagai kontributor CGIF yang juga memegang kekuasaan suara seperti halnya yang dimiliki oleh negara-negara anggota, menjanjikan era baru regionalisme Asia yang mengakui partisipasi lembaga di luar negara. Memang, 
pendekatan yang berpusat pada negara masih tetap menjadi pilihan utama dalam kerja sama keuangan Asia Timur. Namun, keterlibatan ADB dalam proses pengambilan keputusan menjadi bukti bahwa kekuatan regional mulai membuka diri untuk lebih mengakomodir partisipasi aktor di luar negara. Perkembangan ini memperkuat kemungkinan untuk menanamkan nilai-nilai demokrasi lebih kuat di kawasan. Pada akhirnya, penelitian ini memberikan gambaran bahwa prinsip-prinsip demokrasi dapat diadopsi lebih lanjut ke dalam kerja sama keuangan Asia Timur di masa mendatang. Dalam proyeksi jangka panjang, kerja sama keuangan, dapat didedikasikan sebagai kerangka kerja untuk proses domestikasi nilai-nilai eksternal, termasuk prinsip-prinsip demokrasi di luar aspek prosedural.

\section{Referensi}

\section{Buku dan Bab dalam Buku}

Brown, David, 2004. 'The Democratization of National Identity', dalam Henders, Susan J. (ed.), Democratization and Identity: Regimes and Ethnicity in East and Southeast Asia, Lexington Books: Maryland.

Christiansen, Flemming, 1994. "Democratization in China: structural constraints", dalam Gerald P \& Michael M (eds), Democracy and democratization, Routledge: London.

Dahl, Robert A, 1989. Democracy and its critics, Yale University Press: Yale.

Dahl, Robert A, 1998. On Democracy, Yale University Press: Yale.

Delmatino, Frank, 2005. 'The Experience of European Integration in an Historical Perspective", dalam M Woosik \& AO Bernadette (eds), Regional Integration Europe and Asia Compared, Ashgate: England.

Elisabeth, Adriana, 2007. 'The Indonesian Experience in Implementing Democracy", dalam Hasan, Zoya (ed.), Democracy in Muslim Societies: The Asian Experience, Sage Publication India: New Delhi.

Emmerson, Donald K, 2008."Critical terms: Security, democracy, and regionalism in Southeast Asia." Hard choices: Security, democracy and regionalism in Southeast Asia.

Haynes, Jeffrey, 2013. Democracy in the Developing World: Africa, Asia, Latin America and the Middle East. John Wiley \& Sons.

Jomo, K. S, 2010. "Regional financial cooperation in East Asia", dalam U Volz \& A Caliari (eds), Regional and Global Liquidity Arrangements, German Development Institute: Bonn.

Kausikan, B, 1998. 'The "Asian Values" Debates: A View from Singapore', in Larry D \& Marc F.P. (eds), Democracy in East Asia, The John Hopskin University Press, London.

Laffan, Brigid, and Sonya Mazey, 2006.”European Integration: The European Union- 
reaching an equilibrium?”, dalam J. Richardson. European Union. Power and policy making.

Lord, Christoper, 1998. Democracy in the European Union, Sheffield Academic Press: Sheffield.

Reilly, Benjamin, 2006. Democracy and diversity: political engineering in the AsiaPacific Online-Ausgabe,” Druckausgabe: Oxford

Richardson, Jeremy, 2006. 'Theoretical and Historical Perspectives', dalam European Union: Power and Policy-making, Routledge: Oxon.

Saputro, Eko, 2017.Indonesia and ASEAN Plus Three FinancialCooperation: Domestic Politics, Power Relations, and Regulatory Regionalism, Palgrave Macmillan.

Shelly, Becky, 2005. Democratic Development in East Asia, Routledge.

Wood, Alan T, 2004. Asian democracy in world history, Rouletge.

\section{Jurnal dan Jurnal Daring}

Acharya, Amitav, 2010. "Democracy or death? Will democratisation bring greater regional instability to East Asia?”, The Pacific Review, 23 (3): 335-58.

Beeson, Mark, 2003. "ASEAN Plus Three and the Rise of Reactionary Regionalism", Contemporary Southeast Asia, 25 (2).

Chey, Hyoung-kyu, 2009, "The changing political dynamics of East Asian financial cooperation: the Chiang Mai initiative", Asian Survey, 49 (3): 450-67.

Davis, J. Ryan, 2010. "East Asian Regionalism: Origins, Development and Prospects for the Future", Politikon, 16 (1): 34-49.

Green, Michael J \& Daniel Twining, 2008. "Democracy and American grand strategy in Asia: The realist principles behind an enduring idealism", Contemporary Southeast Asia: A Journal of International and Strategic Affairs, 30 (1): 1-28.

He, Baogang, 2004, "East Asian ideas of regionalism: a normative critique", Australian Journal of International Affairs, 58 (1): 105-25.

Hidetaka, Yoshimatsu, 2005. "Political Leadership, Informality, and Regional Integration in East Asia: The Evolution of ASEAN Plus Three", European Journal of East Asian Studies, 4 (2): 205-32.

Jayasuriya, Kanishka, 2009. "Regulatory regionalism in the Asia-Pacific: drivers, instruments and actors", Australian Journal of International Affairs, 63 (3): 33547.

Laothamatas, Anek. 1997. "DEVELOPMENT AND DEMOCRATIZATION A Theoretical Introduction with Reference.” Democratization in Southeast and East Asia 76: 1.

Pempel, Thomas J, 2010. “Soft Balancing, Hedging, and Institutional Darwinism: The 
Economic-Security Nexus and East Asian Regionalism”, Journal of East Asian Studies, 10 (2): 209-38.

Reilly, Ben, 2007. "Political Engineering in the Asia-Pacific", Journal of Democracy, 18 (1): 58-72.

Sen, Amartya Kumar, 1999. "Democracy as a universal value", Journal of Democracy, 10 (3): 3-17.

Shin, Doh Chull, 2008. "The Third Wave in East Asia Comparative and Dynamic Perspectives", Taiwan Journal of Democracy, vol. 4, no. 2, pp. 91-131.

Shin, Doh Chull \& Youngho Cho. 2010, "How East Asians Understand Democracy: From a Comparative Perspective”, ASIEN, 116: 21-40.

Soesastro, Hadi, 2003. "An Asean Economic Community and ASEAN+3: How Do They Fit Together?”, Pacific Economic Papers, 338.

Stubbs, Richard, 2002. “Asean Plus Three: Emerging East Asian Regionalism?', Asian Survey, 42 (3): 440-55.

Suzuki, Sanae, 2004. "East Asian cooperation through conference diplomacy: Institutional aspects of the ASEAN Plus Three (APT) framework", IDE APEC study center working paper series, 3 (04).

Yeo, Lay Hwee, 2010. "Institutional regionalism versus networked regionalism: Europe and Asia compared”, International Politics, 47 (3-4): 324-37.

\section{Artikel Daring}

Asian Development Bank, 2010. "ADB to contribute to ASEAN+3 Guarantee Facility" [daring] http://www.adb.org/media/Articles/2010/13200-asian-creditsguarantees [diakses pada 11 Maret 2011].

Bangko Sentral Ng Pilipinas, 2011. "Chiang Mai Initiative Multilateralisation” [daring] http://www.bsp.gov.ph/downloads/Publications/FAQs/CMIM.pdf [diakses pada 7 September 2011].

Freedom House, 2019. "Reports" [daring] https://freedomhouse.org/reports [diakses pada 28 Mei 2020].

Saputro, Eko NM, 2011. "Where to for ASEAN+3's Macroeconomic Research Office?", East Asia Forum [daring] http://www.eastasiaforum.org/2011/06/18/where-tofor-asean3-s-macroeconomic-research-office/ [diakses pada 29 Juni 2011].

Sen, Amartya, 2003. "Democracy and Its Global Roots", Human Development Resource Net [daring] http://hdrnet.org/462/1/Democracy Global Roots.pdf [diakses pada 10 Maret 2011]. 
Beyond Consensus: Democratic Element in ASEAN Plus Three Economic Cooperation

\section{Lain-lain}

Akhtar, MS, 2004. "Economic integration in East Asia: trends, challenges and opportunities", artikel dipresentasikan pada Symposium The Challenges and Opportunities of Economic Integration in East Asia di the Royal Society, London, 27 October 2004.

Alatas, Ali, 2001. "Asean Plus Three: Equals Peace plus Prosperity", artikel dipresentasikan pada the 2001 Regional Outlook Forum, Bangkok.

ASEAN Plus Three. 2012, "The Joint Ministerial Statement of The $13^{\text {th }}$ ASEAN+3 Finance Ministers' Meeting”, ASEAN Plus Three, Tashkent. 